\title{
COVID-19 Salgınının Çocuklar Üzerindeki Olası Etkileri: İstismar ve İhmal Boyutu
}

\author{
Aynur UYSAL TORAMAN ${ }^{1}$ \\ Ökkeş KISA ${ }^{2}$
}

'Prof. Dr, Ege Üniversitesi Hemşirelik Fakültesi Halk Sağlığı Hemşireliği Anabilim Dalı, Bornova/IZMMiR

${ }^{2}$ Msc.Hemşire, Dr. Behçet Uz Çocuk Hastalıkları ve Cerrahisi Eğitim ve Araştırma Hastanesi, Konak/IZMIR

\section{$\ddot{O} z$}

COVID-19; yüksek ateş ve nefes darlığı ile tanımlanan, damlacık ve temas yoluyla bulaşan yeni viral solunum yolu hastalığıdır. Hastalık; birey, aile ve toplumun sağlığını küresel boyutta etkilemesi nedeni ile salgın olarak adlandırılmaktadır. Salgın, neden olduğu yaşam kayıpları yanısıra oluşturduğu sosyal ve ekonomik sorunlar ile de etkilerini sürdürmektedir. Tarih boyunca görülen küresel salgınlarda olduğu gibi salgının sosyal ve ekonomik sonuçlarından en çok etkilenen grup çocuklar olmuştur. Çocuklar, hastalık açısından doğrudan risk grubunda olmamakla birlikte; yoksullaşma, eğitim, sağlık ve hayatta kalma, güvenlik olmak üzere salgından dört boyutta etkilenmiştir. Bu süreçte çocuklarda; yoksulluk, aile içi şiddet, istismar ve ihmal, korku, stres, endişe ve ruhsal problemler gibi sorunlar oluşmuştur. Özellikle salgın nedeniyle okulların kapanması, evde kalma önlemleri, sosyal mesafe kısıtlamaları, alkol tüketimi ve aile içi şiddette artışın olması gibi birçok etmen bu dönemde çocuk istismarı ve ihmali riskini arttırmıştır. Bu derlemenin amacı, COVID-19 salgının çocuklar üzerindeki etkilerini çocuk istismarı ve ihmali boyutunda literatür doğrultusunda incelemektir.

Anahtar Kelimeler: Çocuk istismarı ve ihmali, Aile içi şiddet, COVID-19 ve Çocuk.

\begin{abstract}
The Potential Impact of The COVID-19 Pandemic On Children: The Dimension of Abuse and Neglect

COVID-19 is a novel viral respiratory disease that is transmitted with droplets and physical contact and is identified with high fever and shortness of breath. The disease is defined as pandemic because of the global pandemic affecting the health of individuals, families, and society. In addition to the loss of lives caused by this pandemic, it also continues to have its effects with the social and economic problems it causes. Children have been the group most affected by the social and economic outcomes of the outbreak, which is the case in global outbreaks throughout history. Although children are not directly included in the risk group for this disease, they are affected in four dimensions by the pandemic; impoverishment, education, health and survival, and safety. In this process, problems like poverty, domestic violence, abuse and neglect, fear, stress, anxiety, and mental problems emerged in children. Many factors like the lock-down of schools, home-stay measures, social distance limitations, alcohol consumption, and increased domestic violence also increased the risk of child abuse and neglect in this period, especially due to the pandemic. The purpose of this review was to examine the effects of the COVID-19 pandemic on children in line with the literature data on child abuse and neglect.
\end{abstract}

Keywords: Child abuse and neglect, Domestic violence, COVID-19 and Child

Geliş Tarihi / Received: 03.03.2021 Kabul Tarihi / Accepted: 15.10.2021

Correspondence Author: Msc.Hemşire, Dr. Behçet Uz Çocuk Hastalıkları ve Cerrahisi Eğitim ve Araşıırma Hastanesi/IZMIR Tel: +905315072630 E-posta: okkeskisa22@gmail.com

Cite This Article: Uysal Toraman A, Kısa Ö. COVID-19 Salgınının Çocuklar Üzerindeki Olası Etkileri: İstismar ve İhmal Boyutu. Dokuz Eylül Üniversitesi Hemşirelik Fakültesi Elektronik Dergisi. 2022; 15(1): 68-77. 
Y eni Koronavirüs Hastalığı (COVID-19), ilk olarak Çin'in Vuhan Şehri’nde Aralık ayının sonlarında ateş, öksürük, nefes darlığı gibi solunum yolu belirtileri ile tanımlanan damlacık ve temas yoluyla bulaşan yeni viral solunum yolu hastalığıdır (1). COVID-19 hastalığı; birey, aile ve toplumun sağlı̆̆ını küresel boyutta etkilemesi nedeni ile Dünya Sağlık Örgütü (DSÖ) tarafından salgın/pandemi olarak tanımlamıştır (2). COVID-19 salgınının ilk olarak ekonomik, sosyal ve eşitsizlik yönünden sonuçları olmuştur (3).

Hastalık, öncelikle yetişkinler ve kronik rahatsızlığı olanları etkilemiştir. COVID-19 hastalığı açısından çocuklar doğrudan risk grubunda olmamakla birlikte, çocuklar salgından yoksullaşma, eğitim, sağlık ve hayatta kalma, güvenlik boyutlarında etkilenmiştir (4). Bu süreç, çocuklarda yoksulluk, aile içi şiddet, istismar ve ihmal, korku, stres, endişe ve ruhsal problemlere neden olmuştur (3,5-6). Bu derlemenin amacı, COVID-19 salgının çocuklar üzerindeki etkilerini çocuk istismarı ve ihmali boyutunda literatür doğrultusunda incelemektir.

\section{COVID-19 Salgını ve Çocuklar}

\section{Gelişme}

COVID-19 pandemisi; doğrudan virüsün bulaşması, salgını durdurmaya yönelik tedbirlerin kısa vadeli sosyoekonomik etkileri ve sürdürülebilir kalkınma hedeflerini uygulama sürecindeki gecikmenin uzun vadedeki olası sonuçları olmak üzere çocukları üç boyutta etkilemektedir (7). Okulların kapanması ve evde kalma önlemleri aile içinde, arkadaş gruplarında ve profesyoneller üzerinde kaynakların sınırlandırılmasına neden olmuştur (8).

Birleşmiş Milletler Çocuklara Yardım Fonu (UNICEF), COVID-19'un sosyoekonomik boyutunun çocuklar üzerinde olumsuz olacağını ve bu durumun da ailelerin yaşadığı finansal problemler nedeniyle çocukların yemek gibi temel gereksinimlerinin ve sunulan bağışılama hizmetlerinin ihmal edilmesine yol açacağını belirtmiştir. Ayrıca UNICEF, salgın nedeniyle şiddet, istismar ve ihmali önlemeye yönelik hizmet sunan okulların kapalı olması, sosyal hizmetlerin salgına yönelik çalışmalara ağırlık vermesi ve acil şiddet/istismar çağrılarına geri dönüş yapan çocuk hizmetlerinin ve sağlık bakım hizmetlerinin ertelenmesinden dolayı çocukların güvenlik ve sağlıklarına yönelik tehditlere maruz kaldıklarını ve kalacaklarını vurgulamıştır (9).

Salgın süreci çocukların eğitim alma şeklini de etkilemiş, birçok ülkede virüsün bulaşmasını önlemek için okullar kapatılmış ve uzaktan eğitim seçenekleri oluşturulmuştur (10). Bu kapsamda her çocuğun uzaktan eğitim için gerekli koşullara ulaşabilme olanaklarının sağlanması gereksinimi doğmuştur. Bundan dolayı UNICEF, bilgisayar ve internete erişimin uzaktan eğitim sürecinin önemli bir faktörü olduğu, evde bilgisayar ve internete erişimin olmamasının çocukların eğitim hayatını olumsuz etkilediğine işaret etmiştir (10). Bununla birlikte çocukların eğitim hayatının uzaktan eğitim ile devam etmesi çocuklarda teknolojinin bir yaşam merkezi haline gelmesine neden olmuştur. Bu durum çocuklarda siber zorbalık, riskli çevrim içi (online) davranış ve cinsel sömürü gibi zararlı çevrim içi davranışlarla karşılaşma risklerinin artmasına neden olmuştur. Dünya Sağlık Örğütü (DSÖ), uluslararası kuruluşlar ile ortaklaşa yayınladığı bir raporunda COVID-19 salgını ile okulların kapanması; öğrencilerde çevrim içi şiddetti artırdığını, öğrencilerin farklı şiddet türlerine maruz kaldığını ve öğrencilerde tekrar okula dönmenin korku oluşturduğunu açıklamıştır (8).

\section{Çocuğa Yönelik Kötü Muamele: İstismar ve İhmal}

Çocuğa kötü muamele "Çocuğun sağlığına, gelişimine ve onuruna karşı gerçek veya potansiyel tehlike oluşturan her türlü fiziksel, duygusal ve cinsel şiddet, ihmal ve çocuğun sömürülmesi için yapılan davranış" olarak tanımlanmıştır (11). Hastalık Kontrol ve Önleme Merkezi (CDC), çocuk istismarı ve ihmalini, 0- 17 yaş çocukluk döneminde meydana gelebilecek potansiyel travmatik olaylarla birlikte sağlı ve refah üzerinde uzun vadeli etkileri olabilen önemli bir halk sağlığı sorunu olarak belirlemiştir (13). Çocukların maruz kaldığı bu kötü muamelenin fiziksel, cinsel, duygusal, ekonomik istismar ve ihmal olmak üzere çok farklı tipleri bulunmaktadır (11). Fiziksel istismar; en geniş anlamda "Çocuğun kaza dışı yaralanması" olarak tanımlanmaktadır. En sık rastlanılan fiziksel şiddet davranışı çocuğu dövmek şeklindedir (13). Fiziksel istismar; bir erişkin tarafindan cezalandırma, disiplin, öfke boşaltma ya da başka amaçlarla elle ya da herhangi bir araç kullanarak çeşitli şekillerde çocuğun bedensel bütünlüğüne zarar veren davranışlardır. Erişkin bir kişinin 18 yaşından küçük genç ve çocukları cinsel istek ve ihtiyaçlarının doyumu için kullanması ise cinsel istismardır (14). Çocukların kendilerine bakmakla yükümlü olan kişiler tarafindan olumsuz tutum ve davranışlara maruz kalarak, gereksinim duydukları ilgi, sevgi ve bakımdan yoksun bırakılmaları duygusal istismar; çocuğun gelişimini engelleyici, haklarını ihlal edici işlerde ya da düşük ücretli iş gücü olarak çalışması ya da çalıştıılması da ekonomik istismar olarak tanımlanmaktadır. Çocuğun bakımı, korunması, güvenliği, beslenmesi, giyim ve eğitim ihtiyaçlarının karşılanması, sağlığının korunması ve tıbbi bakımdan, gözetiminden ve desteklenmesinden sorumlu kişilerin çocuğun bu temel gereksinimlerini ihmal etmesi ve/veya karş̧layamaması sonucu gelişiminin ve güvenliğinin zarar görmesi de çocuğun ihmali olarak kabul edilmektedir $(12,15)$.

Dünyada her yedi çocuktan biri çocuk istismarı veya ihmali yaşamaktadır (12). Dünyada her dört kızdan biri ve her 13 erkekten biri cinsel istismara maruz kalmaktadır (15). Ayrıca 20 yaşın altındaki 120 milyon kız ve genç kadın bir tür zorla cinsel istismara maruz kalmaktadır. Çocuklara yönelik cinsel istismarın \%91'i çocuğun ailesi veya ailesinin tanıdığı tarafından yapılmaktadır (15-16). Çocuk istismarı ve ihmalinin çocuğun yaşamı ve sağlığı üzerindeki etkilerinin yanısıra bu sorunun ekonomik etkilerinin de belirlenmesi sorunun başka bir boyutu ile ele alınmasını sağlamaktadır. Amerika Birleşik Devletleri (ABD) 2015 yılı istatistiklerine göre çocuk istismarı veya ihmali türleri toplamda 428 milyar dolar ekonomik kayba neden olmaktadır. Bu durum, inme ve tip 2 diyabet gibi diğer halk sağlı̆̆ sorunlarıyla yarışmaktadır. Yine ABD (2015) verilerine göre cinsel istismar ve ihmalden dolayı toplam yaşam boyu ekonomik kaybın en az 9.3 milyar dolar olduğu tespit edilmiştir $(12,15$ 16).

UNICEF, 2010 yılı Türkiye raporuna göre; Türkiye'de 9090 hane üzerinde 7- 18 yaş arası 1886 çocuk ile yaptı̆̆ çalışmada son bir yılda çocukların \%25'i ihmale, \%51'i duygusal istismara, \%43'ü fiziksel istismara ve \%3'ü cinsel istismara maruz kalmıştır (17). Çocuk istismarı ve ihmali ile ilgili ASUMA ve IMDAT dernekleri tarafından hazırlanan bir rapora göre ülkemizde 0- 17 yaş arası çocuk mağdur sayısı 2014'te 74.064 iken 2016'da 83.552'ye yükselmiş; 0-17 yaş arası cinsel istismar mağdurların yüzdelikleri 2006 yılında \%42.5 iken 2016'da \%58.8'e yükselmiştir. Ayrıca cinsel suç mağduru olan çocukların sayısı 2014'te 
11.095 iken 2016'da 16.877'ye yükselmiş ve \%33 artış olmuştur. Ocak 2011- Mayıs 2016 arası Çocuk İzlem Merkezi (Çì)'lere Türkiye genelinde 21.068 olgu başvurmuştur. Bu olguların \%85'i kız, \%15'i erkek çocuktur (18). Adli Sicil ve İstatistik Genel Müdürlüğü (2019), 2019 yılı raporuna göre Türkiye'de 2012- 2019 yılları arasında çocukların cinsel istismarı suçundan açılan davalardaki suç sayıları incelendiğinde; 2014 yılına kadar arttığı, 2015 ve 2016 yıllarında azaldığı, 2017 yılında tekrar arttığı ve 2019 yılına ise suç sayısının 22. 689 olduğu tespit edilmiştir (19). Adli Sicil ve İstatistik Genel Müdürlüğü (2020) raporuna göre 17. 948 çocuğa cinsel istismarı suçundan dava açıldığı tespit edilmiştir. Bu sayının önceki yıla göre düşük olmasında COVID19 pandemisinden dolayı evde kalma çağrıları, sokağa çıkma kısıtlamaları ve okulların kapalı olmasının etkili olabileceği düşünülmüştür (20).

\section{COVID-19 Salgınında Çocuk İstismart ve İhmali}

COVID-19 salgınının toplumlarda kötü sağlık sistemi, düşük sosyoekonomik durum, toplumlara daha fazla ekonomik yük getirmesi ve suç oranlarının daha artması gibi sonuçlar ortaya çıkaracağı belirtilmektedir (10). Dünya Sağlık Örgütü (DSÖ), uluslararası kuruluşlar ile ortaklaşa yayınladığı bir raporunda okulların kapanması, ortamdaki belirsizlikler ve birçok stres faktöründen dolayı çocukların savunmasız bir grup haline geldiği ve çevrim içi istismarda artışın olduğu konusunda kamuoyunun dikkatini çekmiştir (8).

COVID-19 salgını bulaşma önlemleri kapsamında okulların ve çocuk kreşlerinin kapanması 1,38 milyar çocuğun okul veya kreş hizmetlerinden mahrum kalmasına yol açmıştır. Bununla birlikte sosyal mesafe önlemleri kapsamında çocukların sürekli evde olması, çocukları istismar ve ihmalin ana kaynağı olarak kabul edilen ebeveynlere daha da yakınlaştırmışıı. Aynı zamanda ebeveynlerde oluşan ekonomik kayıpla birlikte gelecek belirsizliği aile içi dinamikleri etkilemiştir (21). Yapılan bir çalışmada işsizlik oranındaki \%1 artışın çocuk ihmalinde \%20 artışa yol açtığı tahmin edilmektedir. Bu da ortalama ek olarak 536 çocuk ihmali vakası olarak tespit edilmiştir (22).

UNICEF bir raporunda COVID-19 salgınının çocuk istismarı ve ihmali neden olacak faktörleri şu maddeler ile belirtmiştir (4):

- İstihdam ve gelir kaybı nedeniyle artan yoksulluk ve gıda güvensizliği,

- Çocukların eğitime kişisel veya çevrim içi olarak erişememesi,

- Çocuklarda dijital aktivitelerde bir artış ve bakıcıların takibinde bir azalma olmasından dolayı daha fazla dijital risklere maruz kalması,

- Okullar ve bakım programları tarafindan sağlanan besleyici yemeklerin olmaması,

- Çocuklar veya bakıcılar için akran ve sosyal destek ağlarının bozulması,

- Çocuklar/bakıcılar için rutinlerde işlerin bozulması,

- Ergenler/bakıcılarda alkol ve/veya madde kullanımının artması,

- Çocuk bakımı düzenin bozulması,

COVID-19 salgınından korunma tedbirleri kapsamında yapılan evde kalma çağrılarının, sokağa çıkma yasaklarının, okulların kapatılmasının, çocukların olumlu ilişkiler barındıran geniş aile ve toplumsal kaynaklardan aniden koparılmasının çocuk ihmaline neden olduğu belirtilmektedir (23). UNICEF (2020) yayınladığı bir raporda 136 ülkeden 104'ünde çocuklara yönelik şiddete ilişkin hizmetlerin kesintiye uğradığını açıklamıştır. Bu durum ise çocuk ihmalinin bildirilme oranlarında azalışa neden olmaktadır (24). Yapılan bir çalışmada, Uganda'da COVID-19 salgınında çocukların temel ihtiyaçlara sınırlı eriştiği, çocuk istismarı ve ihmali ve çocuk iş̧̧iliği insidansında artı̧̧ olduğu tespit edilmiştir (25). Türkiye'de pandemi döneminde 28 kentte ve 1873 kadının katılımı ile yapılan bir çalışmada 0 - 18 yaş çocuğu bulanan kadınların \%19.3'ü çocuğunun şiddete maruz kaldığını açıklamıştır. Bu çocukların \%53'ünün psikolojik, \%24.8'nin ekonomik, \%12'si dijital, \%7.5'i fiziksel ve \%2.7'i cinsel şiddet gördüğü belirtilmiştir. Şiddete maruz kalan çocukların \%36.2'si babası, \%32.1'i annesi, \%19.7'si kardeşi, \%7.3'ü akraba/tanıdık ve \%4.7'si arkadaşı tarafından şiddet uygulanmıştır. Ayrıca çalışmada çocuk ihmali riski faktörlerinde artış olduğu saptanmıştır (26). Türkiye'de yapılan başka bir çalışmada okul psikolojik danışmanları, pandemi döneminde ebeveynlerin \%43.9'unun çocuklarına karşı ihmalkâr davrandıklarını açıklamıştır. Okul psikolojik danışmanları ihmalin; yetişkinlerin bilgisayar başında geçirdikleri sürede artış olması, çocukların evlerde kalitesiz zaman geçirmesi ve velilerin çocuklara karşı tahammülsüz olmasından kaynaklandığını tespit etmişlerdir (27).

COVID-19 nedeniyle uygulanan fiziksel mesafe, kısıtlamalar, ekonomik kayıplar gibi durumların çocukların ve ergenlerin ruh sağlı̆̆ını önemli ölçüde tehdit ettiği bilinmektedir (6). Bu durum çocuklar üzerinde stres, endişe ve akranlarından ayrı kalma gibi sonuçlar oluşturmaktadır (6). Yapılan bir araştırmada Çin'de ilkokul ve ortaokul öğrencilerine, COVID-19 salgının 1. ve 2. dalgası sonrası okullar açıldığında anket uygulanmıştır. Araştırma sonuçlarına göre COVID-19 salgının 1. dalga sırasında depresif semptom \%18.5 iken 2. dalga sırasında depresif semptom \%24.9'a yükselmiş; 1 . dalga sırasında kendini yaralama $\% 31.8$ iken 2. dalga sırasında kendini yaralama $\% 42.0$ 'a yükselmiş; 1 . dalga sırasında intihar düşüncesi $\% 22.5$ iken 2 . dalga sırasında intihar düşüncesi \%29.7'ye yükselmiş̧; 1. dalga sırasında intihar planı \%8.7 iken 2. dalga sırasında intihar planı \%14.6'ya yükselmiş; 1. dalga sırasında intihar girişimi \%3.0 iken 2. dalga sırasında intihar girişimi \%6.4'e yükselmiştir (28). Yapılan başka bir çalışmada ekonomik durgunluğun yaşandığı dönemlerde çocuk istismarına bağglı kafa travması insidansının iki katına çıktığı ve ölüm oranında ciddi artış olduğu tespit edilmiştir (29). COVID-19 salgınında çocuklara yönelik kaza dışı yaralanma olan fiziksel şiddette; çocuğun duygusal olarak yoksun veya olumsuz davranışlara maruz kaldığı duygusal şiddette ve yaşı küçük bireyin psikososyal gelişimini tamamlamayıp bir yetişkin tarafından cinsel amaçlar için kullanıldığ 1 cinsel şiddet ve türlerinde dikkate değer bir artış olması yönünde öngörü yaygınlaşmaktadır $(6,13)$. Salgının yayılmasını önlemek için uygulanan karantina dönemlerinde çocukların çevrim içi olarak internet ortamında çok zaman harcamaları ve yeni arkadaşlar edinmelerinden dolayı çocuklarda çevrim içi cinsel sömürü riski artmıştır (6).

COVID-19'a bağlı olarak evde kalma çağrıları, ekonomik belirsizlikler, okulların ve kreşlerin kapanması, sosyal mesafe uygulamaları, ailelerde artan bakım yükü, yaşanan stres, işsizlik, düşük gelir, sınırlı kaynaklara ulaşma, alkol tüketiminin artması ve sınırlı sosyal destek gibi faktörler bireylerin mental sağlığını olumsuz etkilemektedir. Bu faktörlerden dolayı COVID-19 
salgınında aile içi şiddet riski artmaktadır. Aile içi şiddet ile birlikte çocuklar olumsuz davranış sergilemektedir $(5,18,30,42)$. ABD'nin Teksas eyaletinde çocuk istismarı ve ihmaline yönelik artış olduğuna ilişkin bilgileri doğrular nitelikte veriler bulunmaktadır. COVID-19 salgını döneminde ABD'nin Houston şehrinde aile içi şiddet, saldırı ve hırsızlık ve Montgomery şehrinde de aile içi şiddet vakalarında artış olduğunu bildirilmiştir $(31,32)$. Amerika Birleşik Devletleri'nde köklü bir kuruluş olan Ulusal Cinsel Saldırı Yardım Hattı (RAINN); tecavüz, istismar ve ensest ilişkiye dair Mart 2020'de yardım hattını arayanlarda \%22 artış olduğunu belirtmiştir. Yardım hattını arayan küçük çocukların \%67'si, failin bir aile üyesi olduğunu ve çocukların \%79'u fail ile birlikte yaşadıklarını açıklamıştır. Evde kalma çağrılarının çocukların ruh sağlığın olumsuz etkilendiğini ve yardım için çağrı hatlarında artışın olmasının beklendiği açıklanmaktadır (33). Avusturya' da COVID-19 salgını başladığından beri genel alkol satışlarında \%20'lik, ailelerde alkol tüketiminde \%70'lik bir yükseliş olduğu saptanmıştır. Alkol tüketim oranlarındaki bu artışın \%28'nin COVID-19 salgınına bağlı endişe ve stresten dolayı olduğu belirlenmiştir. Bu endişe ve stres aile içi şiddeti artıracağından çocuklar da istismarı ve ihmale açık duruma gelmektedir. Bununla birlikte Avusturya'da COVID19 salgını başladığından beri yardım çağrılarında aile içi şiddete bağlı \%11'lik bir artış olmuştur (5). Almanya'da COVID-19 salgını sırasında yapılan bir çalışmada kadınların fiziksel çatışmaya, duygusal istismara, rıza dışı ilişkiye ve 1474 çocuğun fiziksel şiddete maruz kaldığı tespit edilmiştir. Aynı çalışmada evde karantina sürecinin, ekonomik endişeler ve ruh sağlığının olumsuz etkilenmesiyle aile bireyleri arasında fiziksel çatışmanın arttığı tespit edilmiştir (42). Çin'de COVID-19 salgını sırasında yapılan bir çalı̧̧mada ebeveynlerde gelir ve iş kaybının olması ebeveynlerin çocuklarını karşı fiziksel şiddet riskini arttırdığı tespit edilmiştir (43). ABD'de yapılan başka bir çalışmada ise ebeveynlerin COVID-19 sürecinde iş kaybının çocuklar üzerindeki psikolojik ve fiziksel istismar etkisi araştırılmıştır. Yapılan çalışmaya 4- 10 yaş arası çocuğu olan 342 ebeveyn katılmıştır. Çalışma sonunda işini kaybeden ebeveynlerin daha depresif oldukları, çocuklarına psikolojik ve fiziksel olarak kötü davrandıkları ve iş kaybı düzeldikçe fiziksel istismar oranında düşüş olduğu tespit edilmiştir (51). ABD'de COVID-19 salgını sırasında yapılan bir çalışmada, COVID-19 salgını sırasında çocuk istismarı ve ihmalinde dolayı 2020 yılı 29 Mart- 25 Nisan ayının, 2019 yılının 29 Mart- 25 Nisan aylarına göre hastaneye başvuru oranında \%53'lük azalma olduğu fakat hastaneye yatan çocukların oranında artış olduğu tespit edilmiştir. İkibin yirmi yılında hastaneye yatan çocuklar yaş gruplarına göre incelendiğinde 0 - 4 yaş arası hastaneye yatış $2019^{\prime}$ da $\% 3.5$ iken 2020 'de $\% 5.3$ 'e; 5 - 11 yaş arası hastaneye yatış 2019 'da $\% 0.76$ iken 2020 'de \%1.3'e; 12 - 17 yaş arası hastaneye yatış 2019 'da \%1.6 iken 2020'de \%2.2'ye yükselmiştir (49). Kaiser ve arkadaşlarının (2021) yürüttükleri araştırmada, ABD'de COVID-19 salgını sırasında 2020 yılında çocuk istismarı ve ihmali boyutlu yaralanma sayısı, kafa travması geçirme sayısı, hastaneye yatış oranı, hastane içinde ölüm oranın 2019- 2017 yıllarına göre daha yüksek olduğu tespit edilmiştir (50).

Türkiye'de YÖRET vakfı (2020) tarafından hazırlanan bir raporda okul psikolojik danışmanları ve çocukların COVID-19 salgını dönemindeki deneyimleri araştırılmıştır. Çalışmaya katılan okul psikolojik danışmanları; ailelerin pandemi döneminde bilgisayar başında geçirdikleri sürede artış ve tahammül kapasitelerinin azalmasından dolayı çocuklarına karşı şiddet ve ihmal davranışlarının olduğunu belirlemiştir. Çalışmaya katılan çocukların \%83.3'ü psikolojik, \%62.1'i dijital, \%43.9'u fiziksel, \%18.2'si cinsel şiddet, $\% 54.5$ 'i ihmal ve \%30.3'ü tüm şiddet ve ihmal türlerine maruz kaldığı̆, aynı çalışmada pandemi sürecinde çocuklarda öfke, kaygı, korku ve tahammülsüzlüğün arttı̆̆ı bulunmuştur (27).

Mart - Nisan 2019 ve Mart - Nisan 2020 aylarında Çocuk İzlem Merkezi’ne müracaat edilen cinsel istismara maruz kalan 309 olgu incelendiği bir çalışmada, belirtilen bu verilerin tersine pandemi döneminde çocuklarda cinsel istismar risk faktörlerinin artmasına rağmen ihbar edilme oranlarının düştüğü bulunmuştur (34). Çocuk İzlem Merkezi'ne (ÇiM) 25 Mart - 10 Mayıs 2020 tarihleri arasında cinsel istismar nedeniyle müracaat eden 53 olgu değerlendirildiği bir başka çalışmada da olgu sayısının önceki yıllara oranla yaklaşık \%50 oranında azaldığı, aile içi istismar oranlarının önceki yıllarla ve genel literatürle yakın oranlarda olduğu tespit edilmiştir (35). Yapılan her iki çalışmada olgu sayılarının önceki yıllara göre azalmasında, COVID-19 döneminde okulların kapatılması, bildirimlerin azalması gibi faktörlerden dolayı çocuk istismarı ve ihmalinin tespitinin güçleşmesinin etkili olduğu düşünülmektedir. Doğru veriler, ancak toplum normal hayata döndüğünde yapılan araştırmalar sonucunda ortaya çıkacaktır (30).

COVID-19 salgının çocuk istismarı ve ihmali üzerinde dünyadaki yaygınlı̆̆ını gösteren sınırlı çalışmalar mevcuttur (53-54). Yapılan bir çalışmada 16 ülke için twitter üzerinden çocuk istismarı ve ihmaline yönelik kelime analizleri yapılmıştır. ABD'de 20 eyalet seçilerek nefret ve taciz içerikli küfür kullanılan kelimelerin 2020 yılı Mart ayından önce ve sonra için 100.000 nüfus başına kullanılan tweet sayısının analizleri yapılmıştır. Yapılan çalışma sonunda sırasıyla Columbia ve New York bölgesinde Mart ayından önce 100.000 nüfus başına haftalık tweet sayısı 0.26 ve 0.32 iken Mart ayı sonrası 3.55 ve 1.36 olmuş ve seçilen tüm eyaletlerde Mart ayının öncesine göre tweet sayısı artmıştır. Diğer 15 ülke için 2019 yılı Kasım- Aralık ve 2020 yılı MartNisan ayları arasında kullanılan küfürlü tweetlerin sayısı İsveç hariç Endonezya, Filipinler, Portekiz, Brezilya'da \%30'dan fazla artış olmuştur. Ayrıca yapılan çalışmada Reddit analizinde 2019 yılı Nisan ayı ve 2020 yılı Şubat ayı arası aylık kullanılan küfür sayısı, 2020 yılı Şubat- Temmuz ayları arasında aylık kullanılan küfür sayısı istismar türlerine göre kategorize edilerek karşılaştırıldığında fiziksel istismarda \%106, çocuk istismarında $\% 94$, eş istismarında $\% 88$ ve cinsel istismarda $\% 62$ oranında bir artış olduğu tespit edilmiştir (53). ABD'nin New York City, Florida, New Jersey ve Wisconsin eyaletlerinde yapılan bir çalışmada, 2013- 2019 Mart ve Aralık aylarıyla 2020 yılının Mart ve Aralık ayları arasındaki çocuk istismarı ve ihmaline yönelik önlenemeyen çocuk istismar ve ihmali vaka sayısı ile bu vakaların ülkeye maliyeti hesaplanmıştır. Çalışma soncunda 2020 Mart ve Aralık aylarında 623.137 çocuk vakasının araştırılamadığı bulunmuştur. Bu çocukların 85.993 çocuğun önlenebilir hizmetlere erişemediği, 104.040 çocuğun istismar ve ihmale maruz kaldığ 1 ve 48.1 milyar dolar ekonomik kayba neden olduğu tespit edilmiştir (54).

\section{COVID-19 Salgınında Çocuk İstismarı ve İhmaline Yönelik Çözüm Önerileri}

UNICEF bir raporunda COVID-19 salgınının çocuklar üzerindeki etkisini azaltmak için şu tavsiyelerde bulunmuştur (7):

- Ülkelerde uygulanan sokağa çıkma yasağı, sosyal mesafenin olumsuz etkisini hafifletmek ve toplumdaki savunmasız çocuklara erişimi sağlamak için yapılan sosyal programlarda denge kurulmalıdır. 
- Çocuk merkezli hizmetlerin sürekliliği, başta eğitim, beslenme programları, bağışıklık, anne ve yeni doğanlara yönelik hizmetler ve toplum temelli çocuk koruma programları olmak üzere hizmet ve programlara eşit erişim sağlanarak özel önem şartıyla öncelik verilmelidir.

- Ailelere ve bakım veren kişilere yönelik, çocuklarla salgın hakkında nasıl konuşulması gerektiği, kendi ruh sağlklarını ve çocuklarının ruh sağlıklarını nasıl korumaları gerektiği hakkında destek sağlanmalı ve çocukların eğitimine yardımcı olacak destekleyici araçlar sunulmalıdır.

- Mülteciler, yerinden edilen kişiler, evsizler, göçmenler, azınlıklar, gecekondu mahallerinde yaşayan, engeli olan, sokakta yaşayan ve/veya çalışan, mülteci kamplarında yaşayan ve kurum bakımındaki çocuklar da dahil savunmasız çocuklara yönelik özel tedbirler alınmalıdır.

COVID-19 salgını sürecinde çocuk istismarı ve ihmali sorununa çözüm üretirken temel çocuk istismarı ve ihmali önlemleri üzerinden yaklaşılmalıdır. Bu kapsamda aşă̆ıdaki başlıklar üzerinden çözümler gerçekleştirilmelidir:

Hızlı Bir Şekilde Müdahale İçin Erken Tespit: Çocuklara yönelik kötü muamele vakaları çalışmaları raporlanmalıdır. Düzenli olarak toplanan araştırma araçlarında kısıtlama olduğundan, güvenli yardım merkezleri, sosyal yardım merkezleri ve sanal veri toplama gibi araçlar benimsenmelidir. Salgına yönelik kısıtlamalar kalktıktan sonra erken tanı koymak için eğitim programları oluşturup rapor halinde yayınlanmalıdır (3).

Ebeveyn Desteği ve Stresi Azaltma Önlemleri: Yeni anne olan adaylara yönelik yoğun ev ziyareti programlarının çocuk istismarı ve ihmalini azalttı̆̆ı bulunmuştur. Bu hizmetleri COVID-19 salgını nedeniyle çok azalmıştır. Bundan dolayı bu hizmetlere ağılık verilmelidir. Ayrıca sivil toplum kuruluşları, çocukları ve ergenleri destekleyen kuruluşlardan destek alınmalıdır. Ailelere uzun vadede, temel ruh sağlığı ve psikososyal destek hizmetleri sunulmalıdır (3).

Risk Altındaki Ailelere Finansal Destek: Ailelerdeki refah ve güvenliği sağlamak için özellikle savunmasız ailelere ve evli olmayan kişilere finansal destek sağlanmalıdır. Ayrıca hükümetler çocuklarda COVID-19'un oluşturduğu kötü muamelenin gelecekteki riskini azaltmak için hazırlık yapmalıdır. Sosyal hizmet sağlayan ve sağlık hizmeti sunan kurumlar ile birlikte multidisipliner şekilde çalışmalıdır (3). Ayrıca COVID-19 salgınında bireylerin sağlık durumlarını değerlendirmek zordur. Bundan dolayı tele-sağlık hizmetleri sayesinde hizmet sunulmalıdır (6).

Dünya Sağlık Örğütü (DSÖ), uluslararası kuruluşlar ile ortaklaşa yayınladığı bir raporunda COVID-19 salgınında çocuk istismarı ve ihmalinin önlenmesi için kanıta dayalı olarak geliştirilen ve yedi ana başlıktan oluşan "INSPİRE" paket eğitim programının etkili olduğunu ve bu programın hükümetler tarafindan uygulaması için çağrıda bulunmuştur. Bu program şu başlıkları içermektedir (8):

- Kanunların uygulanması ve icrası,

- Normlar ve değerler,

- Güvenli ortamlar,

- Ebeveyn ve bakım verenlere destek,

- Gelir ve ekonomik güçlenme,

- Müdahale ve destek hizmetleri,

- Eğitim ve yaşam becerileri,

Çocuk istismarı ve ihmalinde aileden aileye, toplumdan topluma değişen birçok risk faktörü bulunmaktadır (44). Çocuklar açısından; erken doğum, kronik hastalıklar, anti sosyal arkadaş çevresi, davranış bozuklukları, engellilik gibi faktörlerdir (44). Aile açısından; depresyon, yoksulluk, şiddet, aile yapısı, ayrımcılık, madde bağımlılığı gibi faktörlerdir (44). Çevresel risk faktörleri ise evin durumu ve ailenin sosyal bakımdan izole edilmesi olarak açıklanabilir (44). Bu risk faktörlerini önlemek için birçok model bulunmaktadır (45). Bunlardan bazıları psikiyatrik, sosyolojik, etkileşimsel modellerdir. Bu modeller çocuk istismarı ve ihmalinde önlemede tek bir faktöre odaklandığından eksik kalmaktadır. Bundan dolayı literatürde çocuk istismarı ve ihmalini önlemek için bütüncül yaklaşım olan ekolojik modelin önemli olduğu vurgulanmaktadır (45). Ekolojik Model; birey, aile, grup ve/veya topluluk ile politik, sosyal ve kültürel çevreler arasındaki ilişki ve bağlantıları ve bunların birbirlerini nasıl etkilediğini ve şekillendirdiğini açıklamaktadır (46). Bronfenbrenner (1977) tarafından geliştirilen ekolojik model dört bileşenden oluşmaktadır (46-47):

- Mikrosistem: ev, okul, işyeri,

- Mezzosistem: mikrosistemlerden meydana gelen komşuluk, toplum,

- Ekzosistem: kamu kurumları, profesyonel kuruluşlar,

- Makrosistem: ekonomik ya da siyasal ideolojiler, baskın inançlar ya da basmakalıp düşünceler,

Küresel ölçekte sekiz ülkeden uzman araştırmacıların katıldığı bir çalışmada COVID-19 salgınında çocuğa kötü muamelenin önlemesi için Bronfenbrenner (1977) tarafından geliştirilen ekolojik modelin önemli olduğu vurgulanmaktadır (48).

Yapılan araştırmalarda risk faktörlerinin belirlenmesi, koruyucu faktörlerin arttırılması, uluslararası ortak çalışmalar yapılması ve çocukların güvenliklerinin sağlanması için teori ve uygulamaya yönelik bilgilerin geliştirilmesi ve yenilikçi yaklaşımların oluşturulmasına değinilmiş̧ir (48,51). Küresel ölçekte yapılan çalışmada COVID-19 salgınında ekolojik model çerçevesinde çocuk istismarı ve ihmalini önlemek için risk faktörleri gösteren bir çerçeve oluşturulmuştur (48) (Şekil 1). 


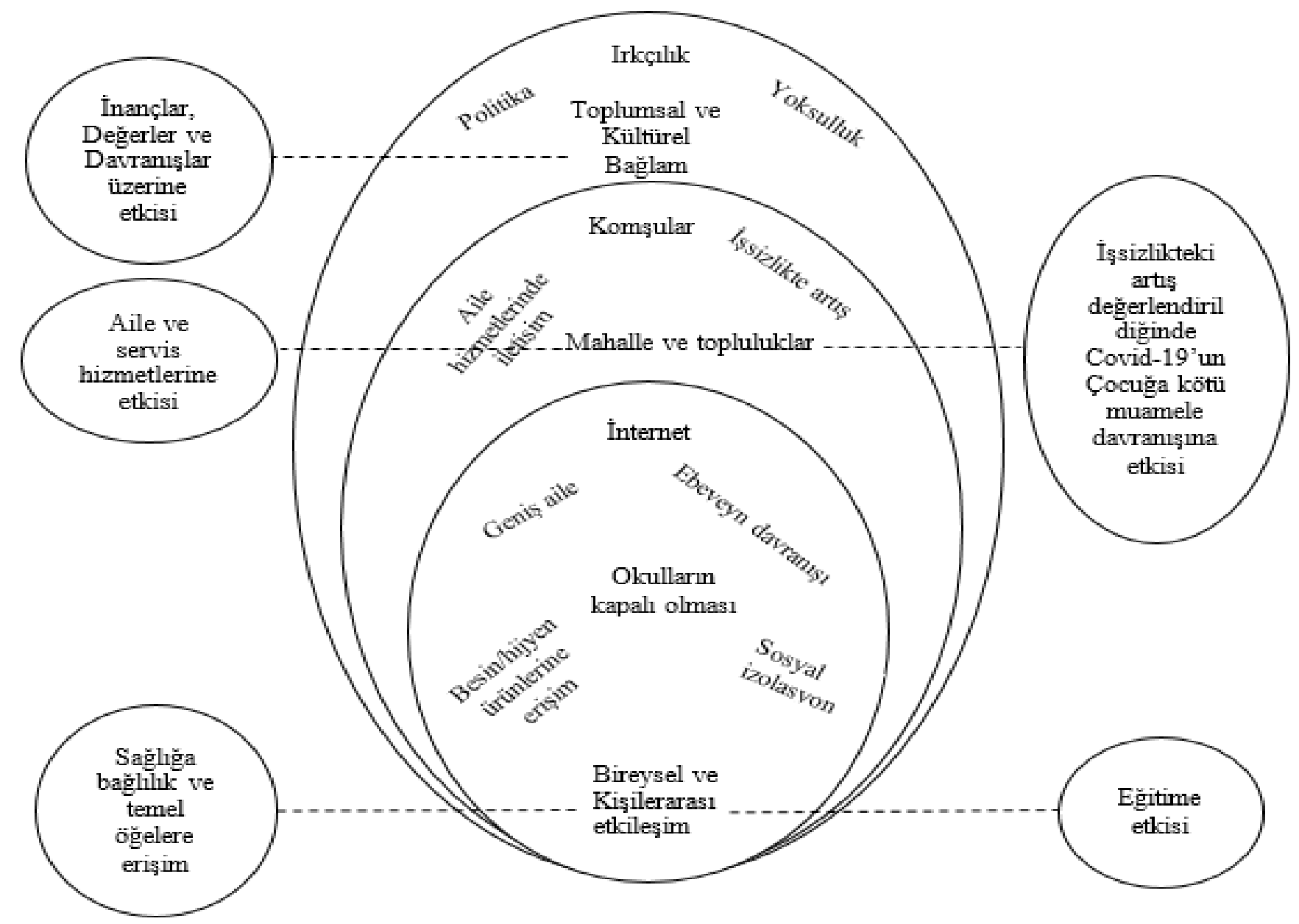

Şekil 1.COVID-19 ve Çocuğa Kötü Muameleyi Önlemek İçin Ekolojik Model (48).

Yukarıda COVID-19 salgını ve çocuğa kötü muameleyi önlemek için oluşturulan ekolojik model, bireysel ve kişilerarası etkileşim açısından incelendiğinden COVID-19'un etkisi her ülkede farklı olduğundan ülkeye özgü ve bölge bazında koruyucu önlemler alınmalıdır. COVID-19'un çocuklarda sağlık sistemine ve politikalara etkisi belirsiz olduğundan durum tespit araştırmaları yapılmalıdır. COVID-19'dan dolayı okulların kapalı olması COVID-19'un öğrencilerde yaş gruplarına yönelik etkisinin araştırılmasına ve koruyucu önlemlerin alınmasına ihtiyaç bulunmaktadır. COVID-19 salgınında internete erişim çocukların eğitim hayatının devamının sağlanması ve akranları ile iletişimde olmaları yönünden koruyucu olmuş ve çevrim içi istismarı artırması yönünden ise risk faktörü oluşturmaktadır. Bundan dolayı çocuklarda etkisi araştırılmalı ve koruyucu önlemler alınmalıdır. COVID-19 salgını cinsiyet eşitsizliğini artırmıştır. Bundan dolayı cinsiyet eşitsizliğini önleyen politikalara yoğunlaşılmalı ve kaynak tahsisi sağlanmalıdır. COVID-19 salgınında sosyal izolasyon, ekonomik sıkıntılar ve profesyonel destek eksikliğinden dolayı engelli çocuklar için istismar ve ihmal riskini artırmaktadır. Bundan dolayı engelli çocuklarda araştırma yapılmalı ve koruyucu önlemler alınmalıdır. COVID-19 salgını daha önce istismar ve ihmale uğramış çocuklarda stresi arttırabilir bundan dolayı bu çocuklarda stresi azaltacak uygulamalara ihtiyaç bulunmaktadır. COVID-19 salgını aile içindeki ilişkiyi olumsuz etkilemiştir. Bundan dolayı COVID-19'un aile içindeki alt öğelere etkisi araştırılmalı ve aile içindeki alt öğelere yönelik müdahale çalışmalarının yapılması gerekmektedir (48).

COVID-19 salgını ve çocuğa kötü muameleyi önlemek için oluşturulan ekolojik model, mahalle ve topluluk açısından incelendiğinde COVID-19 salgını nedeniyle ailelerin içe kapanmaları çocuk istismarı ve ihmalinin ihbar edilme oranını düşürmüştür. Fakat çocuk istismarı ve ihmalinin bildiriminde komşuların önemi artmıştır. Bundan dolayı gelecekte çocuk istismarı ve ihmalinin önlenmesi için komşulara yönelik çalışmalar yapılmalıdır (48).

COVID-19 salgını ve çocuğa kötü muameleyi önlemek için oluşturulan ekolojik model, toplum ve kültür bağlamı açısından incelendiğinde politika, ırkçılık ve yoksulluk faktörleri ortaya çıkmaktadır. Politika olarak her ülke COVID-19 salgınında çocukları koruma yönünden eksiklikleri giderilmeli ve dünya çapındaki kriz dönemlerinde çocukları korumak için küresel politika oluşturulmalıdır. Bununla birlikte çocukları savunan grupların çocukları korumadaki rolleri artırılmalı ve bu gruplara medyada söz hakkı verilerek çocuk hakları konusunda politikalara katılması sağlanmalıdır. COVID-19 salgınında ekonomik kriz ve sosyal izolasyon dezavantajlı gruplara yönelik olumsuz davranışları artırma potansiyeline sahiptir. Bundan dolayı çocuklar ve aileler için risk faktörleri artacaktır. Bu sebeple hükümet yetkilileri gerekli önlemleri almalıdır. COVID-19'dan önceki yoksul aileler ve COVID-19 salgını nedeni ile yoksulluğa maruz kalan çocuklar ve aileler hakkında araştırmalar yapılmalı ve hükümetler bu ailelere ve çocuklara özel politikalar benimsemelidir (48). 
COVID-19 nedeni ile sokağa çıkma yasakları, gelir kaybı, izolasyon, stres ve kaygı nedeniyle kadın ve çocuklar üzerinde cinsiyete dayalı şiddet ve çocuk istismarı ve ihmali oluşmuştur. Oluşan sorunların çözümünde halk sağlığ yaklaşımından yararlanılması önerilmektedir (36). Japonya'da halk sağlı̆̆ hemşireleri, COVID-19 sürecinde çocuk istismarı ve ihmalini azaltmak için online ev ziyareti, online ebeveyn eğitimi, online enfeksiyon önleme programları, yerel yönetimlerde online danışmanlık hizmeti, yüz yüze bireyselleştirilmiş ebeveyn eğitimi, tele-sağlık hizmeti, kargo ile kitap ve broşür hizmeti, istismar ve ihmal riski taşıyan aileleri tespit ve takip hizmeti sunmaktadır (37). Avrupa Birliği (AB) ve UNICEF, COVID-19'un çocuklar ve aileler üzerindeki etkilerini azaltmak için Batı Balkanlarda ve Türkiye'de erken çocukluk, temel sağlık, koruma ve eğitim hizmetlerinin devamlılığını sağlamak için proje başlatmıştır (38). Türkiye'de kamu kurumları veya sivil toplum kuruluşları Japonya, Avrupa Birliği (AB) ve UNICEF yaptığı gibi benzer programlar geliştirmelidir. COVID-19 sürecinde ülkeler uzaktan veya kısıtlı șekilde yüz yüze eğitime devam etmektedir. Bundan dolayı öğretmenlere ve okul personellerine çocuk istismarı ve ihmali hakkında tespit ve müdahale eğitimi verilmelidir (39). Tüm dünya değişen olumsuz sosyoekonomik koşullar, aile içi şiddet ve çocuklarda ihmal ve istismar ile ilişkilidir (40). Hükümetler ise ailelerin yaşadığı ekonomik kayıp ve zorlukları önlemek için istihdamı arttırma, borç erteleme ve vergi muafiyeti gibi önlemler almıştır (41). COVID-19 pandemisinde çocuk istismarı ve ihmalini önlemek adına hükümetler ekonomik programlara önem vermelidir. Türkiye'de YÖRET vakfı tarafından hazırlanan bir raporda pandemi döneminde çocuklarda aile içi şiddet ve çevrim içi cinsel sömürü maruziyetinin arttığı, ruh sağlı̆̆ını olumsuz etkilendiği ve okulların açılması gerektiğine dair tespitler bulunmaktadır (27). Türkiye'de COVID-19 pandemisinin çocuk istismarı ve ihmali boyutunu araştırılması ve gerekli önlemlerin alınması için yapılan çalışma gibi birçok araştırmaya ihtiyaç bulunmaktadır.

\section{Sonuç}

COVID-19 salgını, toplumları ekonomik ve sosyal hayat başta olmak üzere birçok yönden etkilemiştir. Çocuklar ise yoksullaşma, eğitim, sağlık ve hayatta kalma, güvenlik açılarından etkilemiştir. Aile içi şiddet, korku, stres, endişe, akran grubunda ayrı kalma, yakınları tarafindan istismara ve ihmale maruz kalma, ruhsal problemler yaşama gibi sorunlara neden olmuştur. Krizin çocuklar üzerindeki etkisi önceki yıllarda oluşan doğal afet ve salgınlar sonucu yapılan araştırmalara bağlı olarak tahmin edilmeye çalışılmaktadır. Fakat krizin çocuklar üzerindeki etkisi normal hayata dönüldükten sonra yapılan çalışma sonuçlarında ortaya çıkacaktır. Yaşanan COVID-19 salgınında hemşireler, çocuk istismarı ve ihmalini önlemede hizmet sunarken eşitsizlikleri önleme, sosyal adalet ve sağlı̆̆ın korunması ve geliştirilmesi ilkeleri çerçevesinde hizmet vermelidir. Bu doğrultuda çocuk istismarı ve ihmalinin erken tanı ve tedavisinde, önlenmesinde, aile ve toplumu bilinçlendirmede rol alabilir. Tüm sağlık kurumlarında çalışan hemşirelerin COVID-19 salgınında çocuk istismarı ve ihmal konusunda farkındalıkları artıılmalı ve aktif rol almalıdır. Özellikle birinci basamak sağlık kuruluşlarında hizmet sunan hemşireler, COVID-19 salgınında çocuk istismarı ve ihmalini açısından riskli ve dezavantajlı ailelere yönelik ev ziyareti programı düzenleyerek çocuk istismarı ve ihmali hakkında erken tanı, önleme ve farkındalık eğitimi vermelidir. Ayrıca hemşireler, COVID-19 salgınında çocuk istismarı ve ihmali hakkında ailelere çevrim içi eğitim ve danışmanlık hizmeti sunmalıdır. Okulların açılması ile birlikte okul sağlığı hemşireleri; okul görevlilerine ve ailelere farkındalık eğitim programı düzenlemeli, araştırmalar yapmalı ve bu araştırma sonuçları ilgili kurumlara raporlanmalıdır. Bununla birlikte hemşireler savunuculuk rolünü kullanarak istismar ve ihmal saptanan çocuklar için okul görevlilerini bilgilendirmeli ve ilgili kurumlar harekete geçirilmelidir. Hemşireler, COVID-19 salgınında çocuk istismarı ve ihmalini önlemede multidisipliner anlayışı benimsemeli ve ortak çalışmalar yapmalıdır. Ülkemizde COVID19 salgının çocuk istismarı ve ihmalini olan etkisinin ortaya çıkması için çocuk hastaneleri ve çocuk izlem merkezlerine gelen vakalar araştırılarak ulusal bir eylem planı oluşturulabilir.

\section{Bilgilendirme}

Bu derlemeye yazarların katkı oranı beyanı şu şekildedir: fikir ve kavram A.U.T., Ö.K.; tasarım A.U.T., Ö.K.; denetleme A.U.T.; literatür tarama Ö.K.; literatür verilerinin analizi ve yorumlaması A.U.T., Ö.K.; makalenin yazımı A.U.T., Ö.K.; eleştirel düşünme A.U.T., Ö.K. Bu derleme, araştırma ve bilimsel yayın etiğine uyularak yazılmıştır. Araştırmacılar arasında herhangi bir çıkar çatışması bulunmamaktadır. Derleme yazımı ile ilgili herhangi bir kurum ya da kuruluştan destek alınmamıştır. 
1. Pascarella G, Strumia A, Piliego C, Bruno F, Del Buono R, Costa F, et al. COVID-19 diagnosis and management: A comprehensive review. J Intern Med. 2020;288(2):192-206.

2. World Health Organization (WHO). Coronavirus disease (COVID-19) outbreaksituation (2020) [online]. URL: https://www.who.int/emergencies/diseases/novel-coronavirus-2019. 20 Haziran 2020

3. De Cao E, Sandner M. The potential impact of the COVID-19 on child abuse and neglect: The role of childcare and unemployment (2020) [online]. URL: https://voxeu.org/article/potential-impact-covid-19-child-abuse-and-neglect. 21 Haziran 2020

4. United Nations International Children's Emergency Fund (UNICEF). COVID-19: Protecting children from violence, abuse and neglect in the home (2020) [online]. URL: https://www.unicef.org/media/68711/file/COVID-19-Protectingchildren-from-violence-abuse-and-neglect-in-home-2020.pdf. 21 Haziran 2020

5. Bryce I. Responding to the accumulation of adverse childhood experiences in the wake of the COVID-19 pandemic: İmplications for practice. Children Australia 2020;45(2):80-87.

6. Singh S, Roy D, Sinha K, Parveen S, Sharma G, Joshi G. Impact of COVID-19 and lockdown on mental health of children and adolescents: A narrative review with recommendations. Psychiatry research 2020;293:113429.

7. United Nations International Children's Emergency Fund (UNICEF). Politika notu: COVID-19 salgınının çocuklar üzerindeki etkisi (2020) [online]. URL: https://www.unicef.org/turkey/sites/unicef.org.turkey/files/202005/COVID\%2019\%20D\%C3\%B6neminin\%20\%C3\%87ocuklar\%20\%C3\%9Czerindeki\%20Etkilerine\%20\%C4\%B0 li\%C5\%9Fkin\%20Politika\%20Notu.pdf. 22 Haziran 2020

8. World Health Organization (WHO). Global status report on preventing violence against children 2020 (2020) [online]. URL: $\quad$ https://www.who.int/teams/social-determinants-of-health/violence-prevention/global-status-report-onviolence-against-children-2020. 9 Temmuz 2021

9. United Nations International Children's Emergency Fund (UNICEF). COVID-19: Children at heightened risk of abuse, neglect, exploitation and violence amidst intensifying containment measures (2020) [online]. URL: https://www.unicef.org/guineabissau/press-releases/covid-19-children-heightened-risk-abuse-neglect-exploitationand-violence-amidst. 21 Haziran 2020

10. United Nations International Children's Emergency Fund (UNICEF). Data to inform the COVID-19 response (2020) [online]. URL: https://data.unicef.org/resources/data-to-inform-the-covid-19-response/. 21 Haziran 2020

11. World Health Organization (WHO). Report of the consultation on child abuse prevention, 29 - 31 March 1999 (1999) [online]. URL: https://apps.who.int/iris/handle/10665/65900. 20 Haziran 2020

12. Centers for Disease Control and Prevention (CDC). Preventing child abuse \& neglect (2020) [online]. URL: https://www.cdc.gov/violenceprevention/childabuseandneglect/fastfact.html. 22 Haziran 2020

13. Polat O. Şiddet. Marmara Üniversitesi Hukuk Fakültesi Hukuk Araştırmaları Dergisi 2016;22(1):15-34.

14. Garbarino J, Kostelny K. Child maltreatment as a community problem. Child Abuse Negl 1992;16:455-64.

15. Centers for Disease Control and Prevention (CDC). Preventing child sexual abuse (2020) [online]. URL: https://www.cdc.gov/violenceprevention/childsexualabuse/fastfact.html. 24 Haziran 2020

16. World Health Organization (WHO). Child maltreatment (2020) [online]. URL: https://www.who.int/news-room/factsheets/detail/child-maltreatment. 20 Haziran 2020

17. United Nations International Children's Emergency Fund (UNICEF). Türkiye'de çocuk istismarı ve aile içi şiddet araştırması (2010) [online]. URL: http://www.unicef.org.tr/files/bilgimerkezi/doc/cocuk-istismari-raporu-tr.pdf. 21 Haziran 2020

18. İstanbul Acıbadem Mehmet Ali Aydınlar Suç ve Şiddetle Mücadele, Uygulama ve Araştırma Merkezi (ASUMA) ve Şiddeti Önleme ve Rehabilitasyon Derneği (IMDAT). Türkiye'de çocuk istismarı raporu-2 (2018) [online]. URL: https://cohum.giresun.edu.tr/Files/ckFiles/cohum-giresun-edu-tr/RAPOR-\%C3\%87OCUK-

\%C4\%B0ST\%C4\%B0SMARI-tam_v2_cleancopy.pdf. 17 Haziran 2020

19. T.C. Adalet Bakanlığı Adli Sicil ve İstatistik Genel Müdürlüğü. Adli istatistikler-2019 (2019) [online]. URL: https://adlisicil.adalet.gov.tr/Home/SayfaDetay/adli-istatistik-2019-yayini10062020050051. 18 Haziran.2020.

20. T.C. Adalet Bakanlığı Adli Sicil ve İstatistik Genel Müdürlüğ̈̈. Adli İstatistikler 2020 (2020) [online]. URL: https://adlisicil.adalet.gov.tr/Home/SayfaDetay/adli-istatistikler-2020-kitabi-yayimlanmistir22042021025204. 11 Temmuz 2021

21. Cluver L, Lachman JM, Sherr L, Wessels I, Krug E, Rakotomalala S, et al. Parenting in a time of COVID-19. The Lancet 2020;395(10231):e64.

22. Brown D, De Cao E. Child maltreatment, unemployment, and safety nets (2020) [online]. URL: https://papers.ssrn.com/sol3/papers.cfm?abstract_id=3543987. 22 Haziran 2020

23. United Nations International Children's Emergency Fund (UNICEF). COVID-19: çocukları evdeki şiddet, istismar ve ihmalden korumak (2019) [online]. URL: https://www.alliancecpha.org/en/system/tdf/library/attachments/vac turkish translation.pdf?file=1\&type=node \&id= 39021. 10 Temmuz 2021

24. United Nations International Children's Emergency Fund (UNICEF) Araştırmasına göre koronavirüs, 100'den fazla ülkede çocuk koruma hizmetlerinin sekteye uğramasına neden oluyor (2020) [online]. URL: https://www.unicef.org/turkey/bas\%C4\%B1n-b\%C3\%BCltenleri/unicef-ara\%C5\%9Ft\%C4\%B1rmas\%C4\%B1nag\%C3\%B6re-koronavir\%C3\%BCs-100den-fazla-\%C3\%BClkede-\%C3\%A7ocuk-koruma. 12 Temmuz 2021

25. Sserwanja Q, Kawuki J, Kim JH. Increased child abuse in Uganda amidst COVID-19 pandemic. J Paediatr Child Health 2021;57(2):188-191. 
26. Sosyo Politik Saha Araştırması Merkezi. COVID-19 karantinasından kadının etkileşimi ile kadın ve çocuğa yönelik şiddete ilişkin Türkiye araştırma raporu (2021) [online]. URL: https://sahamerkezi.org/wpcontent/uploads/2020/04/kad\%C4\%B1n-covid-ek.pdf. 12 Temmuz 2021

27. Toplumsal Gelişim ve Eğitim Vakfı (YÖRET). Pandemi döneminde çocuğa karşı şiddet ve ihtiyaç analiz raporu (2020) [online]. URL: https://www.stgm.org.tr/sites/default/files/2020-11/1711202014242337.pdf. 10 Temmuz 2021

28. Zhang L, Zhang D, Fang J, Wan Y, Tao F, Sun Y. Assessment of mental health of chinese primary school students before and after school closing and opening during the COVID-19 pandemic. JAMA network open 2020;3(9):e2021482.

29. Huang MI, O'Riordan MA, Fitzenrider E, McDavid L, Cohen AR, Robinson S. Increased incidence of nonaccidental head trauma in infants associated with the economic recession. J Neurosurg Pediatr 2011;8(2):171-6.

30. Campbell AM. An increasing risk of family violence during the Covid-19 pandemic: Strengthening community collaboration stosavelives. Forensic Science International: Reports 2020;2:100089.

31. Alexander C. Montgomery County's DA's office sees 35 percent increase in domestic violence cases during coronavirus isolation (2020) [online]. URL: https://www.khou.com/article/news/crime/montgomery-county-sees-risein-domestic-violence-cases-amid-covid-19-isolation/285-73af4c37-6e66-4785-a421-5e3de0f97cf2. 28 Haziran 2020.

32. CW39. Houston COVID-19 update: Increased cases; domestic violence, assault, burglary also up (2020) [online]. URL: $\quad$ https://cw39.com/news/local/houston-covid-19-update-increased-cases-domestic-violence-assault-burglaryalso-up. 28 Haziran 2020

33. RAINN. For the first time ever, minors make up half of visitors to national sexual assault hotline (2020) [online]. URL: https://www.rainn.org/news/first-time-ever-minors-make-half-visitors-national-sexual-assault-hotline. 28 Haziran 2020

34. Aslan F, Timur S, Pakiş I. COVID-19 pandemisinden etkilenen çocuk istismar olgularının değerlendirmesi. Adli Tıp Bülteni 2020;25:40-47.

35. Güney SA, Bağ Ö. Ülkemizde COVID-19 pandemisi nedeniyle uygulanan karantina süreçlerinin başlangıç döneminde çocukluk çağı cinsel istismarına ait özellikler. Turk J Child Adolesc Ment Health 2021;28(1):27-34.

36. Chandan JS, Taylor J, Bradbury-Jones C, Nirantharakumar K, Kane E, Bandyopadhyay S. COVID-19: A public health approach to manage domestic violence is needed. Lancet Public Health 2020;5(6):e309.

37. Honda C, Yoshioka-Maeda K, Iwasaki-Motegi, R. Child abuse and neglect prevention by public health nurses during the COVID-19 pandemic in Japan. Journal of Advanced Nursing 2020;76(11):2792-2793.

38. United Nations International Children's Emergency Fund (UNICEF). Avrupa Birliği ve UNICEF, COVID-19'un çocuklar ve aileler üzerindeki etkisini azaltmak için Batı Balkanlar'da ve Türkiye'de bir program başlatıyor (2021) [online]. URL: https://www.unicef.org/turkey/bas\%C4\%B1n-b\%C3\%BCltenleri/avrupa-birli\%C4\%9Fi-ve-unicefcovid-19un-\%C3\%A7ocuklar-ve-aileler-\%C3\%BCzerindeki-etkisini. 9 Temmuz 2021

39. Thomas E. Y. Anurudran A, Robb K, Burke T. F. Spotlight on child abuse and neglect response in the time of COVID19. The Lancet Public Health 2020;5(7):e371.

40. Usher K, Bhullar N, Durkin J, Gyamfi N, Jackson D. Family violence and COVID-19: Increased vulnerability and reduced options for support. Int J Ment Health Nurs. 2020;29:549-52.

41. Eroğlu E. Covid-19'un ekonomik etkilerinin ve pandemiyle mücadele sürecinde alınan ekonomik tedbirlerin değerlendirilmesi. International Journal of Public Finance 2020;5(2):211-236.

42. Ebert C. Steinert JI. Prevalence and risk factors of violence against women and children during COVID-19, Germany. Bulletin of the World Health Organization 2021;99(6):429-438.

43. Wong JY, Wai AK, Wang MP, Lee JJ, Li M, Kwok JY et al. Impact of COVID-19 on child maltreatment: Income instability and parenting 1ssues. Int J Environ Res Public Health 2021;18(4):1501.

44. Akçe İ, Doğan H. Cinsel istismara maruz kalmış çocuklar üzerine bir değerlendirme. Sosyal Çalışma Dergisi 2020;4(1):12-20.

45. Türkkan T, Odacı H. Bülbül K. Çocuk istismarı ve ihmalini anlamak: Ekolojik bir yaklaşım. Toplum ve Sosyal Hizmet 2021;32(2):709-728.

46. Paslı F. Cinsel istismara uğrayan çocukların ekolojik sistem yaklaşımı açısından incelenmesi. Gazi Üniversitesi Sağlık Bilimleri Dergisi 2017;2(2):39-53.

47. Paslı F. Çocuğa yönelik cinsel istismar deneyiminin mikro ve mezzo sistemler açısından incelenmesi. Toplum ve Sosyal Hizmet 2019;30(2):463-492.

48. Katz C, Priolo Filho SR, Korbin J, Bérubé A, Fouché A, Haffejee S et al. Child maltreatment in the time of the COVID19 pandemic: A proposed global framework on research, policy and practice. Child Abuse Negl. 2021;116(2):104824.

49. Swedo E, Idaikkadar N, Leemis R, Dias T, Radhakrishnan L, Stein Z, et al. Trends in U.S. emergency department visits related to suspected or confirmed child abuse and neglect among children and adolescents aged $<18$ years before and during the COVID-19 pandemic - United States, January 2019-September 2020. MMWR Morb Mortal Wkly Rep 2020;69:1841-1847.

50. Kaiser SV, Kornblith AE, Richardson T, Pantell MS, Fleegler EW, Fritz CQ, et al. Emergency visits and hospitalizations for child abuse during the COVID-19 pandemic. Pediatrics 2021;147(4):e2020038489.

51. Katz C, Fallon B. Protecting children from maltreatment during COVID-19: Struggling to see children and their families through the lockdowns. Child Abuse Negl. 2021;116(2):105084.

52. Lawson M, Piel MH, Simon M. Child maltreatment during the COVID-19 pandemic: Consequences of parental job loss on psychological and physical abuse towards children. Child Abuse Negl. 2020;110(2):104709. 
53. Babvey P. Capela, F. Cappa C. Lipizzi C. Petrowski N. Ramirez-Marquez J. Using social media data for assessing children's exposure to violence during the COVID-19 pandemic. Child Abuse Negl. 2021;116(2):104747.

54. Nguyen LH. Calculating the impact of COVID-19 pandemic on child abuse and neglect in the U.S. Child Abuse Negl. 2021;118: 105136. 